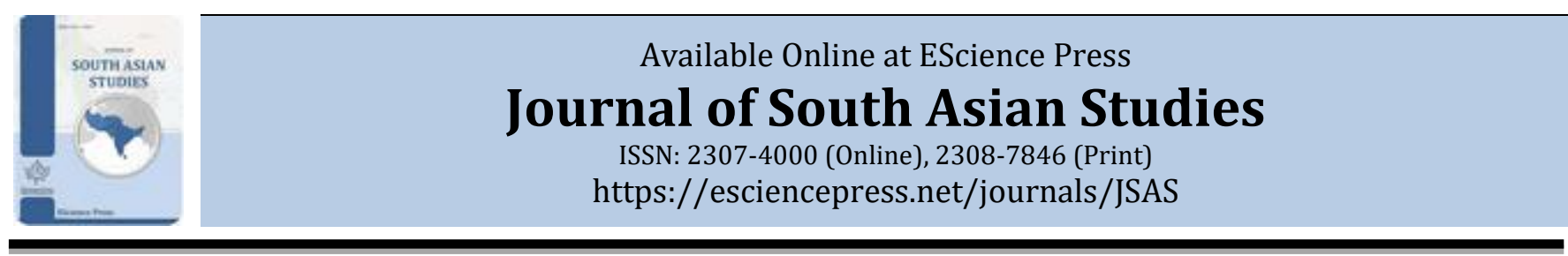

\title{
Socio-Economic Policy Imperatives for Sustainable Food System in Pakistan
}

\author{
Touqeer Ahmada, Abdul Saboorb, Irfan A. Baigc, Aneela Afzald \\ a Department of Economics, PMAS Arid Agriculture University Rawalpindi, Pakistan. \\ b Faculty of Social Sciences, PMAS Arid Agriculture University Rawalpindi, Pakistan. \\ ${ }^{c}$ Faculty of Social Science and Humanities, Muhammad Nawaz Sharif University of Agriculture Multan, Pakistan. \\ ${ }^{d}$ Department of Sociology and Anthropology, PMAS-Arid Agriculture University Rawalpindi, Pakistan.
}

*Corresponding Author Email ID: drabdul.saboor@uaar.edu.pk

\section{A B S T R A C T}

The deadly waves of COVID-19 have exposed especially the food and health systems around the world. The purpose of this research study is to analyze the linkages of socio-economic factors encroaching on sustainable food systems and ultimately food security. Moreover, the policy twist is required to contrive a holistic and integrated approach for the formulation and implementation of workable public policies to materialize the true dream of a sustainable food system. Multinomial Logistic Regression has been applied to estimate the results. The results reveal the story that the independent variables like subsidized fertilizer availability, seeds productivity performance, changing pattern of sowing, and adaptation to climate change have a high positive and statistically significant relation with crops productivity. Moreover, inputs price volatility and changing sowing patterns have a positive and statistically significant impact on adaptation to climate change. Climate change and the current application of research and development ( $R$ and $D$ ) showed a negative impact on production. These results bring forth two dimensional (Alpha and Beta) set of policies to rearrange formulation and implementation frameworks. The former emphasizes food baskets acquisition, investing a large amount in health and environment friendly activities. The latter focuses on riskaversion based healthcare system, food price regulatory framework, and balancing the social-ecosystem.

Keywords: Socio-economics, Food system, Adaptation, Food baskets, Food sustainability, Implementation framework.

\section{INTRODUCTION}

Agriculture especially crops farming is the preeminent business sector that has a direct impact on natural phenomena particularly climate change (Mahmood et al., 2021). Enviable weather conditions are still essential for crops production and food supply despite the significant advancements in technology (Jha, 2015). Rainfall and temperature among the climatic factors determine crops productivity (Akhtar et al., 2019). Crops' productivity is heavily under pressure with the varying intensity of climate change particularly in the low-income and developing agrarian economies. Rural livelihoods are also jeopardized in the developing world while vulnerability to farming communities is burgeoning over time (Abid et al., 2019). The agriculture sector absorbs 60 percent of the workforce, provides 70 percent livelihood opportunities and 22 percent contributes to gross domestic product (GDP) in South Asia (Wang et al., 2019). Weak adaptative capacity and large dependency on the agriculture sector in South Asia are extremely vulnerable to climate change (Mahmood et al., 2021). The frequent increase in the floods, heatwaves, droughts, and precipitation variation in this region have been impacting the food security and livelihood opportunities of the people (Lobell et al., 2012). It has been predicted that GDP will decline around 1.8 percent till 2050 and 8.8 percent by 2100 of the South Asian countries if the effective adaptation strategies are not practiced (Ahmed and Suphachalasai, 2014). Adaptation practices are the specific activities performed in agriculture that are basically designed to increase resilience and decrease vulnerability in the whole agriculture system (Vogel and Meyer, 2018). The adaptation measures' selection largely depends upon 
households' perception towards climate change, geographical location, economic endowments, cultural and social concepts, and a country's agricultural policy (Bryan et al., 2013). Diversified practices of farming could be beneficial to halt the negative impacts of climate change to safeguard, sustainable food supply, food security, and livelihoods of the farming communities (Di Falco et al., 2011). Effective support and small landholder farmers' empowerment to adopt environment friendly and climate resilient practices need to assess the basic motivations for the adoption strategies (Ali, 2021).

In the most vulnerable countries, Pakistan stands among one of the top ten in which climate change has been affecting adversely (Kreft et al., 2014). Pakistan is an agrarian-based economy and agriculture is considered the backbone of Pakistan's economy. Agriculture contributes 19.3 percent to the national GDP in which livelihoods of 38.35 percent population (including 30.2 percent males and 67.2 percent female) depend on the agriculture sector (GoP, 2014). The successfully achieving substantial food supply system lies in investigating the new trends impacting agriculture sustainable productivity and policies implementation response of the farmers. In this way, a policies framework can be devised for a workable policy imperative to develop a mutation in the agriculture sector against any shock to dismantle the whole food supply system. The world population is projected to increase from 7.7 billion (2019) to 9.7 billion (2050) with 2 billion people appearing in 30 years. The advent of coronavirus (COVID-19) has increased human suffering with economic disruption and projected that global annual GDP growth will be shrunk to 2.4 percent (Chakraborty and Maity, 2020).

Political scientists generally give less attention and focus to outcomes from diseases, but they do emphasize behaviors of governments and societies. For instance, how individuals fail or succeed to overcome problems and during crisis correlate risks with economies collapse or natural calamities. The evidence suggested the way forward to focus on strengthening state capacity in addressing mortality during COVID-19 rather than the accountability of citizens by the government (Bosancianu et al., 2020). The Price Theory is one of the foundations of Neoclassical Economics. Price is the cornerstone determinant of consumers' economic welfare and income level of farmers, exporters, and importers who are involved in agriculture products (Sardar Shahraki et al., 2019; Van Campenhout et al., 2018). Subsidized modern inputs would make the farmers able to cover their costs rather than provide credits to them. Free seeds with a reduced price of fertilizers for each crop can develop local labouring wage rates and this model can lead to intensification across the regions (Pretty et al., 2011). However, efficient pesticides application with seeds and standard mixtures of fertilizers nutrients relies on the experience and skills of the farmers (Reader et al., 2018). On the other side, the structure of market connectivity (farm level to retail) and the price transmission process have remained the key areas of discussion among agricultural economists (Amrouk et al., 2020; Hussein, 2018). In the gambit of food and nutrition security, we are going to build a novel narrative by connecting policies in terms of formulation and implementation to achieve a sustainable food supply. This research study is unique in analytically presenting the policy implementation responses of the experts. The efforts are made to devise a basket of policies to achieve an uninterrupted food supply system in the light of socio-economic imperatives.

Agriculture markets analysis is imperative for developing a sound policymaking framework by understanding the relationship between inputs and crops along with their price effects. 'Zero budget' is cognate to financial inputs affordability through which poor farmers overcome their inability of access to improved seed, manufactured agro-chemicals and confront a vicious circle of debt owing to high costs of productions, soaring interest rates, and market prices volatility. This tautness resulted in higher suicide rates over to 2530 farmers who took their own lives since 1995 in India (Smith et al., 2020; Collective, 2012). Farmers continuously deal with climatic uncertainty and variability, however, is looming on the head the uncertain pattern of weather has been demanding rapid and flexible capacity responses. Resilience creation focuses on the risk of being food insecure reduction and developing the adaptive capacity to proactive response and copping risk to change (Gitz and Meybeck, 2012). A sustainable diet is related to the governance of future food systems on a sustainable footing, and it constitutes four goals including nutritious diet and health, cultural acceptance, economic soundness, and environmental auspices (Fanzo et al., 2012). 
The alarming situation has been calling for institutions and governments to transform policy focus by switching off to economic growth and switching on to an economy of conservation that will help to stop environmental degradation and stimulate human activities to attain a sustainable future for all (Ripple et al., 2018). The toughest world societal challenges are minimization of biodiversity losses and attaining sustainable food production that provides unavoidable trade-offs between environment and human axes belonging to sustainable development goals (SDGs) of the UN (Nilsson et al., 2016). Achieving wheat self-sufficiency by providing subsidies on wheat flour prices, managing procurement, and income support. Moreover, Private storage and wheat procurement left a heavy cost on the national exchequer of Rs. 262.5 billion and Rs. 414 billion payables to the banks in Pakistan. They directed policy by insisting on a comprehensive food security policy which must include institutional development based on research and development (R and D) including defined government role in the food sector. The numerous policy measures to perform in a better way in the areas of malnutrition and climate change lie outside the spectrum of health and climate that demands coordination among sectors at multi-levels within and outside the of the governments. Though, this creates problems of power and interests of the powerful policy players to influence the decisions and priorities of the government (Townsend et al., 2020).

The condition of sustainability is satisfied when cost, duration, and dependent activities chain are met with demand (Zachary, 2014). Human and wildlife have been bearing costs due to environmental degradation. Since 1970 , vertebrate populations dropped down on average of 60 percent while 75 percent of the Earth's land has been substantially degraded (Laybourn-Langton et al., 2019). The discourses of distributive justice for climate change lie in mitigation and adaptation (Posner and Weisbach, 2010). Inertia in the climatic system, despite effective mitigation efforts at the global level for greenhouse gases (GHGs), do matter less, humanity will be at risk because of direct and indirect climate change impacts (e. g by ecosystem services) on human wellbeing and will need substantial adaptation efforts (Pachauri et al., 2014). Burgeoning inequality can approach environmental degradation with agricultural frontiers enlargement (Ceddia, 2019). Inequality in the context of wealth concentration in super-rich hands caused impacts on the environment and outstanding consumption patterns (Otto et al., 2019). When there increases one percent in the number of high-net-worth individuals (HNWI), it will result in a 2.4 percent to 10 percent expansion in the area size of flex-crop (Ceddia, 2020). Moreover, inequality has been exacerbating the polluter's marginal benefits (MBs) and reducing marginal costs (MCs) that have been resulting in environmental degradation at a high social optimal level (Boyce et al., 1999).

However, uneven land distribution may increase deforestation and impact demographics (Sant'Anna, 2017). Environmental protection may also be hindered as inequality (Andersson and Agrawal, 2011). Hence, over the past 30 years, global inequality is mainly resulted due to an increase in the accumulation of wealth among the richest people (Alvaredo et al., 2018; Galbraith, 2012). Forward-looking (distributive justice; distribution of risk damages cannot be adapted) and backward-looking (compensatory justice; compensation to those who are suffering from climate change from those who caused or right of compensation by agents) policies are highly focused for food sustainability. The distributive justice (ability to bear the principal payment) states that the agents who have the ability or capacity to manage residuary risks should bear a large portion of costs and should deliver this bulk of benefits to the agents who have the greatest financial need, i.e., available global resources (Wallimann-Helmer et al., 2019). Interdisciplinary and intersectoral approaches like structural changes are to be followed with trade regimes to mitigate climate change and reduce malnutrition along with reasons for change identification and how these changes are accomplished by actors of public interest (Friel et al., 2020).

\section{MATERIALS AND METHODS}

\section{Theoretical background}

The program theories or theories of change are the approaches for theory-oriented evaluation (Koleros and Mayne, 2019). The Theory of Change (ToC) is based on the "hope to change some of what" (Valters, 2014). Food security is a multi-sectoral and multi-dimensional phenomenon that expands beyond food production, availability, and food demand (Reddy, 2015). Agriculture is the most implicitly and explicitly influential sector in the context of human development and food security (Abdelhedi et al., 2020; Kogo et al., 2020). Demand and 
supply are the two key aspects of agriculture that are under serious threat of COVID-19 (Siche, 2020). The major determinants of demand sides are purchasing power, population growth, subsidies, food products prices, social welfare programs, and schemes while the supply side is food production size at the domestic level, food imports, and food distribution (Reddy, 2015). The forthcoming decades are expected to increase pressure globally on food systems from the demand side (burgeoning population growth and per-capita consumption) as well as from the supply side (large inputs competition and climate change challenge). Therefore, there are needed actions regarding food systems, reducing food waste, moderating demand, improving governance, and food production at a large scale (Godfray, 2014). Provision of access to reproductive units of healthcare, ameliorating education (especially girls) have a positive impact on reducing the fertility rate, improving the wellbeing and livelihoods of the hapless (Ezeh et al., 2012). There are also certain other approaches for the production process that are Cobb-Douglas Production Function (Butsic et al., 2012). Moreover, the Stochastic Frontier Production Function does investigate the interregional agriculture average yield difference at a global scale (Kudaligama and Yanagida, 2000). Generalized Cobb-Douglas Production Function gives returns to scales (how output varies with inputs). Moreover, consumption theories include the consumer in classical thought, the Marxian view, the marginalist revolution, Lancaster's objective theory of demand, and Becker's economic theory of taste (Aiello et al., 2012).

\section{Data related framework}

A questionnaire was constructed innovatively for the field survey, and it was conducted in September 2018. Qualitative questions were included with a 5-LikertScale compass. The sample size was determined by Multistage Proportionate Stratified Cluster Random Sampling (MPSCRS). The MPSCRS is applied to homogeneous groups or similar characteristics of the population. In each group sample size is proportionate to the population size of that group. The formula used in sample selection is $n=\frac{\mathrm{N}}{1+\mathrm{N}(e)^{2}}$ (Sani et al., 2019; Singh and Masuku, 2014). Where " $n$ " represents total samples, " $\mathrm{N}$ " indicates the size of included population and "e" is the precision level. According to this formula, 71 percent samples belong to the rural population (9472020 and 29 percent to the urban (422538) population. Among this, 255 respondents were farmers. The minimum age of the respondent was 35 years because there has been used recall method to analyze the perception of the farmers about the policies connected to and implemented in the farming sector of the region. The studied area is comprised of district Chiniot, Punjab, Pakistan. There were three levels or categories (Tehsils or zones) of a district. Therefore, the data were collected from 75 villages (rural) and 3 cities (urban) with the geographical categorization of each category or group or zone into North, South, East, West, and Centra. The basic reason for conducting this field survey was that to analyze the policy effects particularly the heavy flood of 2015 in this reason.

\section{Analytical framework}

Discrete selection analysis is related to the development of model selection from a small set of discrete choices. Probit or logit models are frequently used for the binary selection or choice categories (Kohansal et al., 2013; Riddington et al., 2000) Multinomial logistic analysis is applied for the prediction of categorical arrangements or probability of the category group for dependent variable relies on multiple independent variables (can be dichotomous; binary, continuous; ratio or interval in scale). Moreover, this approach is considered attractive and powerful for analysis because it does not assume linearity, normality, and homoscedasticity (Starkweather and Moske, 2011).

In this research study, there are more than two independent variables in categorical form. Therefore, multinomial logistic regression is a very effective tool to analyze the choices of the respondents. Multinomial logistic model (MNLM) is applied for the analysis of primary choices of consumers. The MNLM exemplifies an appropriate theoretical account to explain and explore a process where the set of choices is comprised of multiple alternatives (Greene, 2008). The multinomial logistic regression is used generally ineffective way where the response variable is in more than two categories or levels and there is needed to predict the response variable along with the percentage of variance in it that is explained by explanatory variables (El-Habil, 2012). This model explains the consumers' behaviors when they have a variety of goods for the objective of common consumption. However, goods and their substitutes or complements must be differentiated by their individual preferences of attributes. MNLM has 
been applied in many research studies particularly related to food security estimations (Udomkun et al., 2018; Ogundari, 2017; McCordic, 2016; Ionescu-Ittu et al., 2015; Carter et al., 2014; Akter et al., 2014; Dean et al., 2011; Temple, 2008; Kabbani, 2005). The analysis of consumers' primary choices is the choice set consists of more than two alternatives (Kohansal et al., 2013). The Multinomial Logistic Model is as follow;

$$
P_{i j}=\frac{1}{1+\sum_{k=1}^{n=5}\left(\operatorname{Exp}\left(\beta_{\mathrm{i}} x_{j}\right)\right.}, \text { if } j=0
$$

Where $P_{i J}$ is the ith households probability indicator in all four key dimensions, $x$ is the vector of variables related to each dimension of the FS that is related to household's socio-economic and demographic aspects (see; variables list in table), $\beta$ is a vector of estimated parameters and $j$ represents the Likert scales perception of household to the parameters of each dimension. The empirical model is explained and defined in the established framework such as;

Model $1 \quad F F A_{F}(A P)=\beta_{0} F_{r} A+\beta_{1} S A+\beta_{2} S P P+$ $\beta_{3} A M C+\mu_{i}$

Where $F A_{F}$ shows Food Availability of farmers that is determined by $A P$ that represents agriculture production, $\mathrm{F}_{\mathrm{r}} \mathrm{A}$ is fertilizer availability, $\mathrm{PA}_{\mathrm{v}}$ is pesticides availability, $\mathrm{SA}_{\mathrm{v}}$ is seeds availability, CSP is changing sowing pattern, $A M C$ is adaptation steps to mitigate climate change and $\mu_{\mathrm{i}}$ is the regression error term.

Model $2 F F S(A C C)=\beta_{1}+\beta_{2} I P V+\beta_{3} C S P+\beta_{4} C P D+$ $\beta_{5} E R D+\theta_{i}$

Where ACCC explicates adaptation to climate change, $I P V$ reflects input price volatility, CSP is changing sowing pattern over time, $C P D$ exhibits the productivity of the crop decreasing over time, $E R D$ is the layout of more expenditure on $\mathrm{R}$ and $\mathrm{D}$ causing lower production while $\theta_{i}$ is the error term in the regression model.

\section{Factor Component Analysis}

Factor analysis is an important instrument that is used for the construction, elaboration, and evaluation of measures, tests, and scales (Williams, Onsman, and Brown, 2010). Moreover, it reduces the number of variables into a small set along with constructs dimensions underlying between measured factors and constructed latent (Taherdoost, Sahibuddin, and Jalaliyoon, 2014). Food security has multidimensional nature and therefore difficult to capture all angles through a single indicator (FAO, 2014). There is needed to include all forms of food security dimensions to measure food security (Pinstrup-Andersen, 2009). FCA is required minimum correlation of 0.30 size among variables and theoretically very first factor captures maximum variations while subsequent capture new with lower variation (Wineman, 2016).

\section{Data Reliability Test}

The Cronbach's alpha tests are applicable when there are multiple Likert scale questions. The questions estimate the latent variables that may be hidden or unobservable. The Cronbach's alpha talks about how closely a set of items are related in a group. Cronbach's alpha depicts the average of the all-possible split-half reliabilities predicted the number of measures in the scale (Zeller, 2005). The value of Cronbach's alpha approaches to one is considered the strong reliability and 0.70 is acknowledged is the threshold for good reliability. In the first model of food availability, Cronbach's alpha value is 0.757 while in the second model of food sustainability, its value is 0.798 . The detail results of reliability have been presented in appendix $\mathrm{C}$ to Appendix F.

\section{RESULTS AND DISCUSSION}

\section{Descriptive results of food availability (model 1)}

In model 1 of food availability; the dependent variable is farmers' understanding about "crops production is decreasing" over time. The processing summary of the model presented in appendix A shows that 42.5 percent of farmers agreed that their agriculture production is decreasing over time while 69.4 percent gave a neutral response and 21.9 percent disagreed with this perception in the whole sample within the farming community. The results indicate that production has been declining. It may be due to climate change, increasing costs of production, input-output market malfunctioning, or used to conventional approaches of production. The impact of rainfall and temperature causing a negative impact on wheat production in rainfed and irrigated regions of Punjab, Pakistan that is ultimately leading to under pressure food availability due to climate change and rising population (Tariq et al., 2014). In appendix A, the dependent variable is agriculture production decreasing over time and independent variables are the perceptions of farmers about this statement and their impacts on the dependent variable. The results of the model's goodness of fit provide support and predict further analysis. Appendix A also shows the validity and efficiency of estimates. The 
value of Chi-Square (129.66) is very high from the likelihood estimated with zero probability value that means the null hypothesis is rejected and the alternative hypothesis is accepted. It also means that regressors have a strong impact on the probability of crops productivity decreasing over time. This means that the estimated model is well fitted. Pearson determined value is insignificant (0.09probability value) and value of deviance is highly insignificant. The null hypothesis for goodness-of-fit is that the observed data is having the goodness of fit with the fitted model or the observed data is consistent with the fitted model. The alternative hypothesis is tha the observed data is not consistent with the fitted model. Therefore, the probability value of Pearson is greater than 0.05 so we reject the null hypothesis and accept the alternative hypothesis. This also indicates to the good-fitted model the result of which also signifies for the implication and validation. The Pseudo R-square value indicates that 47 percent variation of vulnerability in crops production decreasing is due to the independent variables while 53 percent vulnerability variation is due to other factors (finance, import, and export policy measures).

\section{Coefficients results under multinomial logistic regression}

In table 1, the multinomial logistic regression results are presented that include the dependent variable (crops production is decreasing over time) and independent variables (fertilizer availability at government subsidized rate, seeds productivity performance, changing pattern of sowing, and adaptation steps for climate change). All the explanatory variables to crops productivity decreasing are highly statistically significant. The farmer's perception of crops production decreasing is determined through Likert Scales of five options (strongly agree, agree, neutral, disagree, and strongly disagree) and results are shown in table 1 with these five categories. The 'strongly disagree with the base-category for the crop productivity in the estimation.

Table 1. Coefficient results of food availability.

\begin{tabular}{llcccc}
\hline \multicolumn{2}{c}{ Crops productivity decreasing over time } & B & Std. Eror. & Sig. & Exp(B) \\
\hline Strongly Agree & Intercept & -15.96 & 3.40 & 0.00 & \\
& Seeds productivity performance & 2.19 & 0.70 & 0.00 & 8.91 \\
& Fertilizer availability at government subsidized rate & 1.18 & 0.49 & 0.02 & 3.25 \\
& Changing pattern of sowing & 2.83 & 1.11 & 0.01 & 17.09 \\
& Adaptation steps for climate change & 0.63 & 0.77 & 0.41 & 1.87 \\
\hline Agree & Intercept & -8.38 & 2.48 & 0.00 & \\
& Seeds productivity performance & 1.35 & 0.62 & 0.03 & 3.86 \\
& Fertilizer availability at government subsidized rate & 0.86 & 0.38 & 0.02 & 2.36 \\
& Changing pattern of sowing & 1.51 & 0.97 & 0.12 & 4.5 \\
& Adaptation steps for climate change & 1.22 & 0.71 & 0.05 & 3.39 \\
\hline Neutral & Intercept & -7.66 & 3.40 & 0.02 & \\
& Seeds productivity performance & 0.88 & 0.72 & 0.22 & 2.42 \\
& Fertilizer availability at government subsidized rate & 0.77 & 0.47 & 0.10 & 2.16 \\
& Changing pattern of sowing & 2.031 & 1.29 & 0.11 & 7.61 \\
& Adaptation steps for climate change & -0.07 & 0.92 & 0.94 & 0.93 \\
\hline Disagree & Intercept & -0.56 & 2.19 & 0.79 & \\
& Seeds productivity performance & 0.57 & 0.62 & 0.35 & 1.77 \\
& Fertilizer availability at government subsidized rate & 0.12 & 0.38 & 0.75 & 1.12 \\
& Changing pattern of sowing & 0.15 & 0.92 & 0.87 & 1.16 \\
& Adaptation steps for climate change & 0.41 & 0.72 & 0.57 & 1.50 \\
\hline
\end{tabular}

Source: Authors own calculations.

Seeds productivity performance

In table 1, the slope coefficient of "seeds productivity performance" is 2.19 which is statistically significant at a probability value of 0.00 at "strongly estimates". This 
variable has a 1.35 value of slope coefficient at a probability value of 0.03 under "agree" estimates. It means that crops productivity will increase when seeds productivity increased. It is the case that used seeds are sufficient in efficiency and quality to stimulate crops productivity due to climate change impact and lack of resistance to diseases. Moreover, some other factors that may cause soil fertility may be increasing over time, a shift in the production of the crop, and lack of climate change resistance seeds application in the studied area. The annual 80 percent seeds requirements are fulfilled by uncertified seeds (Rana et al., 2018; Abid et al., 2015) and dealers related to inputs sell generic pesticide unauthorized and non-registered seeds (Joshi et al., 2015). Most of the farmers apply last year's used crop seeds due to economizing their costs but they can lose potential yield by using a modern variety of seeds (Fatima et al., 2015). Delay in irrigation can also cause a negative association with the efficiency of some inputs like seeds, fertilizers, and chemicals (Manjunatha et al., 2016).

\section{Subsidized Fertilizer availability}

The slope coefficient of the explanatory variable "Fertilizer availability at government subsidized rate" is 1.18 that is statistically significant under strong estimates. In the "agree estimates" the slope coefficient value of "Fertilizer availability at government subsidized rate" is 0.86 and statistically significant at 0.00 probability. These results give the meaning that if the subsidized fertilizer availability increases to 1.18 and 0.86 percent, the production of the crop will increase accordingly. It also means that with the existed subsidized fertilizer availability, crops productivity has been increasing. In irrigated land, farm-yard manure and fertilizers have a positive link to land preparation and production while wheat yield has been declining (Hussain et al., 2014). The institutional potential and regulatory mechanism in the fertilizer industry failed to operate at full potential in terms of utilization on crops and has been keeping under stress the sustainability of the agriculture productivity (Ali et al., 2015). Fertilizer consumption, credit distribution, and improved seed distribution have a positive and significant impact on agriculture's domestic gross product in Pakistan (Rehman et al., 2019).

\section{Changing pattern of sowing}

The slope coefficient value is 2.83 of independent variable "Changing pattern of sowing" and it is statistically significant at the probability value of 0.01 with "strongly agree estimates. However, this variable also exhibits the same pattern under "agree estimates" with slope coefficient value of 1.51 while it is insignificant at a probability value of 0.121 . It means in the former results that with the current adaptation measures to mitigate climate change, crops productivity is increasing over time. Agriculture is the major sector that is affected by climate change and factors causing impacts on production are rising temperature, evapotranspiration, rainfall pattern, changing patterns of sowing and harvesting, water availability, and land suitability (Janjua et al., 2010). The alternation in sowing baseline dates in the challenging era of climate change is a better option to reduce crops' water requirements (Bhatti et al., 2018).

\section{Adaptation steps for climate change}

However, the slope coefficient of variable "adaptation steps for climate change" value is 0.63 but insignificant (0.14 probability value) at "strongly agree" estimates and but it is significant at "agree estimates" with a slow coefficient value of 1.22 (at probability value of 0.05 ). It means that adaptation steps for climate change have a significant association to cause an increase in crops productivity and there may be other factors involved for increasing crops productivity but farmers who gave understanding for "agree estimates" indicate that this variable has a link to increase crops production. The practicing measures to mitigate climate change impacts are affecting positively and there are also needed workable measures like keep without sowing land for some duration after plaguing to gain soil fertility, changing time of sowing, and harvesting, and best irrigation management. In table 1 , the explanatory variables like seed productivity performance (slope coefficient value is 0.88 at probability value of 0.22 ), subsidized fertilizer availability (slope coefficient value is 0.77 at probability value of 0.10 ), changing pattern of sowing (slope coefficient value is 2.03 at probability value of 0.11) and adaptation step for climate change variable (slope coefficient value is -0.07 at probability value of 0.94) have an insignificant association and positive relation except adaptation steps to mitigate $\mathrm{CC}$ to depend variable "crops productivity is increasing over time". It means that farmers are very clear and confident about their decision and statements for crops production increasing time. In the case of "disagree estimates," all the independent variables contradict and show insignificancy with strongly agree and agree with choices of the Likert Scale in table 2. The slope coefficient of "seed productivity 
performance $£$ is 0.57 (probability value is 0.35 ). the slope coefficient of subsidized fertilizer availability is 0.12 (at probability value of 0.75 ), changing pattern of sowing slope coefficient value is 0.15 (at probability value of 0.87 ) and the adaptation step for climate change variable slope coefficient value is 0.41 (at probability value of 0.57). These results show that farmers disagree about crops productivity is increasing over time. The increase in crops productivity depends upon many other factors like agriculture credit, water availability, pesticides application, soil fertility, experience, and education of farmers.

Multinomial logistic regression results regarding food sustainability (Model 2)
In model 2, the dependent variable is "adaptation to climate change". Farmers gave their perception about how factor is affecting their adaptation measures to mitigate climate change impact. The dependent variables include "input price volatility", "changing sowing pattern", "crops productivity decreasing over time", and "expenditure on R and D causing lower production". The $\mathrm{R}$ and $\mathrm{D}$ have negative relation in the short-run on production (Hussain et al., 2019). The processing summary of model 2 is presented in appendix B. The results also show that 47.8 percent of farmers strongly agree and agree that adaptation mitigates the climate change impact while 46.3 percent disagreed, and 1.6 percent are strongly disagreed with the statement.

Table 2. Results of coefficients for food sustainability.

\begin{tabular}{llcccc}
\hline & Adaptation to climate change & B & Std. Error & Sig. & Exp (B) \\
\hline \multirow{2}{*}{ strongly Agree } & Intercept & 0.49 & 3.36 & 0.88 & \\
& Inputs price volatility decreasing & 2.44 & 1.10 & 0.03 & 11.44 \\
& Changing sowing pattern & 0.07 & 1.26 & 0.95 & 1.07 \\
& Crops productivity decreasing over time & -0.39 & 0.59 & 0.50 & 0.67 \\
& Expenditure on R and D causing lower production & -1.08 & 0.49 & 0.03 & 0.34 \\
\hline Agree & Intercept & 0.89 & 3.130 & 0.77 & \\
& Inputs price volatility decreasing & 1.87 & 1.08 & 0.08 & 6.51 \\
& Changing sowing pattern & 1.31 & 1.18 & 0.26 & 3.69 \\
& Crops productivity decreasing over time & -0.37 & 0.57 & 0.51 & 0.69 \\
& Expenditure on R and D causing lower production & -0.86 & 0.43 & 0.04 & 0.42 \\
\hline Neutral & Intercept & -3.05 & 3.63 & 0.40 & \\
& Inputs price volatility decreasing & 1.42 & 1.14 & 0.22 & 4.13 \\
& Changing sowing pattern & 3.07 & 1.29 & 0.02 & 21.64 \\
& Crops productivity decreasing over time & -0.38 & 0.66 & 0.56 & 0.68 \\
& Expenditure on R and D causing lower production & -1.22 & 0.56 & 0.03 & 0.29 \\
\hline Disagree & Intercept & 3.38 & 3.11 & 0.27 & \\
& Inputs price volatility decreasing & 1.36 & 1.08 & 0.21 & 3.91 \\
& Changing sowing pattern & 1.46 & 1.16 & 0.21 & 4.30 \\
& Crops productivity decreasing over time & -1.33 & 0.57 & 0.02 & 0.26 \\
& Expenditure on R and D causing lower production & -0.51 & 0.42 & 0.23 & 0.60 \\
\hline
\end{tabular}

Source: Author's Calculation.

The goodness of fit is determined through the value of Pearson. The null hypothesis is "the observed data shows the goodness of fit with fitted model" while the alternative hypothesis shows "observed data does not have the goodness of fit with the fitted model". The probability value of Chi-Square is greater than 0.05 and null hypothesis is accepted, and it is concluded that observed data is consistent with the fitted model. The
Pseudo R-Square in the Multinomial Logistic model shows the proportion of variance that is explained by the explanatory variable on the explained variable. Its range is between zero to one. In table 2, the coefficients' results of model 2 are demonstrated. The independent variable "inputs price volatility decreasing" has a positive and statistically significant (0.027) association on the dependent variable "adaptation to climate change 
with the value of 2.44. It means that when the input price volatility decreases, the probability of 2.44 will increase the farmers' adaptation to mitigate climate change impact. At the neutral option of the Likert -scale in model 2, changing sowing pattern has also a positive and statistically significant relationship with the adaptation to climate change. The value of the coefficient is 1.42 and the probability value is 0.018 . It means that people's response is neutral about the changing sowing pattern that can mitigate the impact of climate change.

However, on strongly agree, agree, disagree, and strongly disagree, this variable is insignificant. The explanatory variable "crops productivity decreasing over time" has a positive but insignificant association at strongly agree, agree, and neutral options but it has statistically significant at disagreeing. It means that people disagree that with operational adaptation steps to mitigate climate change impact, crop productivity has been decreasing over time. Moreover, expenditure on $\mathrm{R}$ and $\mathrm{D}$ causing lower production has also negative $(-1.08)$ relation with the adaptation to climate change. It means that as expenditure on $\mathrm{R}$ and $\mathrm{D}$ has been increasing but productivity is decreasing, resultantly adaptation to mitigate climate change will fall. It also gives the story that, current expenditure on $\mathrm{R}$ and $\mathrm{D}$ has not been effective in Pakistan and still productivity has been declining. The agreed results show that all independent variables are insignificant except "expenditure on $\mathrm{R}$ and D causing lower production" with negative relation to the dependent variable. The adaptation can be reactive or proactive processes and farmers' capabilities of expectations and flexibility play a key role in these processes (Robert et al., 2016). Adaptation reflects the degree through which a system does adjust processes, structure, and practices to offset or moderate the change in its environment (Martin, 2015). Farmers have major concerns risks and they are exposed to climate change, pest attacks, institutional risks (regulations in agriculture, sanitary, and environment), and impacts of market risks associated with input and output prices (Hardaker, 2004). The neutral estimates tell that "Changing sowing pattern", and "expenditure on R and D causing lower production" has a statistically significant relationship while the former variable has a positive association with adaptation to climate change and later has negative relation $(-1.22)$. However, they disagree results show that only "crops productivity decreasing over time" has a statistically significant and negative impact. The results discussions give the vision for the future researchers that a sustainable food system can be achieved by examination of policies through holistic nature. Moreover, future researchers should give more intention to policy implementation side.

\section{Policies implications and recommendations}

- The alpha policy is required to ensure food system and strengthen market regulation

- Moreover, the Alpha policy paradigm emphasizes on the health system to be risk-aversion against any shock likewise pandemic that has exposed the health system.

- Alpha policy dimension also recommends the climate friendly activities particularly in the agriculture sector and preferably less focus on fertilizer and pesticides applications for farm productivity.

- Beta policy framework focuses on the implementation side of the public policies

- A sustainable food system can be achieved by alleviating the problems in the existing food price regulatory mechanism and efficiency is achievable through an effective mechanism.

- Healthcare units and health systems are needed a large investment to develop resistance against any shock.

- In Beta policy, sustainability of productivity is a prerequisite for a sustainable food system. Its dream cannot be materialized without creating balance in the societal-ecosystem parallelly.

Baskets of policy required to materialize the dream of food security

An interdisciplinary approach based on the canvas of micro, meso, and macro policy tools regarding all four dimensions of food security including nutritional security is required to address the complexities. The policy package emphasized on holistic approach regarding all dimensions and actions are aligned to achieve food availability, the government needs to control price in inputs market like fertilizers, pesticides, water irrigation, machinery and it will be more effective if targeted subsidy to the targeted farmers with targeted inputs in specified areas is provided. Democratic governance is a necessary condition for accomplishing this task along with efficient institutional performance. Amidst the rising population along with weak economic and physical accessibility, demand for food would be seriously 
escalating. Therefore, effective population control through awareness and social safety nets are required. Mitigation and adaptations measures should be highly encouraged, and effects of climate change farmers at large scales are motivated in their practices at farm levels to minimize the. Uninterrupted food supply is closely aligned with food sustainability. It is the cornerstone because it is standing at large on the performance of the rest of the dimensions of food security. Its assurance in the world of coronavirus is quite difficult. However, its achievability lies primarily on emissions control, the happiness of the people, efficient management in the trade-off between humans and the ecosystem by limiting negative human actions and gaining positive responses from nature. Alpha policies are defined as those that have linkages to policies formulation while Beta policy is defined here through which policies implementation can be improved.

Table 3. Key Findings.

\begin{tabular}{|c|c|c|c|c|c|c|}
\hline $\begin{array}{c}\text { F.S } \\
\text { Dimensions }\end{array}$ & $\begin{array}{l}\text { Variables } \\
\text { Category }\end{array}$ & Variables (MNLM) & Cof. & Sig. & Likert Scale & Key Findings \\
\hline \multirow[t]{5}{*}{$\begin{array}{l}\text { Food } \\
\text { Availability } \\
\text { (F. A) }\end{array}$} & $\begin{array}{l}\text { Dependent } \\
\text { Variable }\end{array}$ & $\begin{array}{l}\text { Crops productivity } \\
\text { decreasing over } \\
\text { time }\end{array}$ & & & \multirow{5}{*}{$\begin{array}{l}\text { Strongly } \\
\text { agree=1 } \\
\text { Agree=2 } \\
\text { Neutral=3 } \\
\text { Disagree=4 } \\
\text { Strongly } \\
\text { Disagree=5 }\end{array}$} & \multirow{5}{*}{$\begin{array}{l}\text { - The likelihood ratio test } \\
\text { results indicate that all } \\
\text { independent variables are } \\
\text { statistically significant. } \\
\text { - The independent variables } \\
\text { like fertilizer availability at } \\
\text { government subsidized rate, } \\
\text { Seeds productivity } \\
\text { performance. } \\
\text { - changing pattern of sowing } \\
\text { and adaptation to climate } \\
\text { change have positive and } \\
\text { statistically significant } \\
\text { relation with dependent } \\
\text { variable crops productivity is } \\
\text { decreasing overtime at the } \\
\text { response of strongly agree. }\end{array}$} \\
\hline & \multirow[t]{4}{*}{$\begin{array}{l}\text { Independent } \\
\text { Variables }\end{array}$} & $\begin{array}{l}\text { Seeds productivity } \\
\text { performance }\end{array}$ & 2.19 & $\begin{array}{l}0.002 \\
(\mathrm{~S} . \mathrm{A}, \mathrm{A})\end{array}$ & & \\
\hline & & $\begin{array}{l}\text { Fertilizer } \\
\text { availability at } \\
\text { government } \\
\text { subsidized rate } \\
\end{array}$ & 1.18 & $\begin{array}{l}0.016 \\
(\mathrm{~S} . \mathrm{A}, \mathrm{A})\end{array}$ & & \\
\hline & & $\begin{array}{l}\text { Changing pattern of } \\
\text { sowing }\end{array}$ & 2.83 & $\begin{array}{l}0.011 \\
(\mathrm{~S} . \mathrm{A}) \\
\end{array}$ & & \\
\hline & & $\begin{array}{l}\text { Adaptation steps } \\
\text { for climate change }\end{array}$ & 1.22 & $0.048(\mathrm{~A})$ & & \\
\hline \multirow{6}{*}{$\begin{array}{l}\text { Food } \\
\text { Sustainability } \\
\text { (F. Ss) }\end{array}$} & Dependent & Adaptation to & & & \multirow{6}{*}{$\begin{array}{l}\text { Strongly } \\
\text { agree }=1 \\
\text { Agree=2 } \\
\text { Neutral=3 } \\
\text { Disagree=4 } \\
\text { Strongly } \\
\text { Disagree=5 }\end{array}$} & \multirow{6}{*}{$\begin{array}{l}\text { - Independent variables: } \\
\text { agriculture income is } \\
\text { increasing at response of } \\
\text { 'agree' has affirmative and } \\
\text { significant relation to the } \\
\text { response of climate stuck } \\
\text { productivity. } \\
\text { - The variable 'adaptation to } \\
\text { CC effects' has also positive } \\
\text { and significant relation but at } \\
\text { the response of disagree. } \\
\text { - Input price volatility and } \\
\text { agriculture extension } \\
\text { department performance } \\
\text { have negative but significant } \\
\text { relation to independent } \\
\text { variables. }\end{array}$} \\
\hline & Variable & climate change & & & & \\
\hline & \multirow[t]{4}{*}{$\begin{array}{l}\text { Independent } \\
\text { Variables }\end{array}$} & $\begin{array}{l}\text { Inputs price } \\
\text { volatility } \\
\text { decreasing } \\
\end{array}$ & 2.44 & $\begin{array}{l}0.03 \\
(\mathrm{~S} . \mathrm{A})\end{array}$ & & \\
\hline & & $\begin{array}{l}\text { Changing sowing } \\
\text { pattern }\end{array}$ & 0.07 & $0.00(\mathrm{~A})$ & & \\
\hline & & $\begin{array}{l}\text { Crops productivity } \\
\text { decreasing over } \\
\text { time }\end{array}$ & -1.33 & $\begin{array}{l}0.02 \\
\text { (D.A) }\end{array}$ & & \\
\hline & & $\begin{array}{l}\text { Expenditure on } \\
\text { R\&D causing lower } \\
\text { production }\end{array}$ & -1.22 & $0.03(\mathrm{~N})$ & & \\
\hline
\end{tabular}




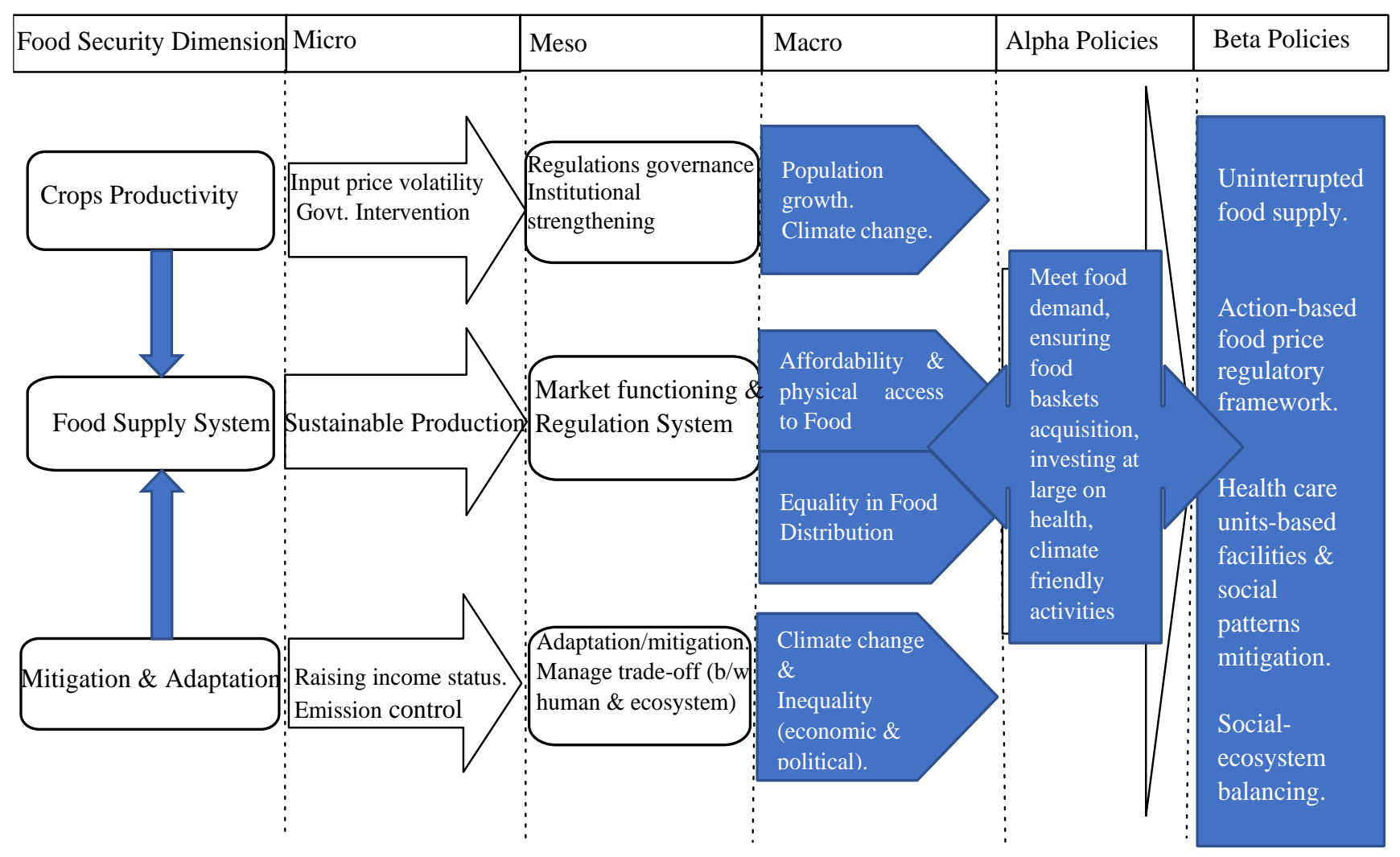

Figure 1. Policy model of change towards sustainable food supply.

Source: Figure is drawn by the authors.

\section{CONCLUSION}

Food security is the cornerstone, and its provision is fundamental for the survival and stability of society. The results tell the story that the independent variables like fertilizer availability at government subsidized rate, seeds productivity performance, changing pattern of sowing, and adaptation to climate change have positive and statistically significant relation crops productivity in case of food availability. The results of food sustainability show that inputs price volatility decreasing and changing sowing pattern have positive and statistically significant association on adaptation to climate change while declining crops productivity and expenditure on $\mathrm{R}$ and $\mathrm{D}$ showed negative relation with adaptation to climate change. In the light of these findings, alpha and beta policies are suggested to successfully tackle the complex nature of food and nutrition security. The alpha policies are required to meet food demand, ensure food baskets acquisition, investing largely in health and environment friendly activities. The beta policies are recommended for uninterrupted food supply, action-based food price regulatory framework, health care unit-based facilities, mitigation of social patterns, and balancing the socialecosystem.

\section{ACKNOWLEDGEMENTS}

We would like to thank the farmers who participated in this survey. We also do acknowledge the PMAS Arid Agriculture University for providing documentation support for conducting our research endeavor. We do also thank Dr. Imran Shah, the University of Bath, and Dr. Issam Malki, the University of Westminster London for Proofreading.

\section{REFERENCES}

Abdelhedi, I. T., and Zouari, S. Z. (2020). Agriculture and Food Security in North Africa: A Theoretical and Empirical Approach. Journal of the Knowledge Economy, 11(1), 193-210. https://doi.org/10.1007/s13132-018-0528-y.

Abid, M., Scheffran, J., Schneider, U. A., and Elahi, E. 2019. Farmer perceptions of climate change observed trends and adaptation of agriculture in 
Pakistan. Environmental management, 63(1), 110123. https://doi.org/10.1007/s00267-018-11137.

Abid, M., Scheffran, J., Schneider, U. A., and Ashfaq, M. J. E. S. D. (2015). Farmers' perceptions of and adaptation strategies to climate change and their determinants: the case of Punjab province, Pakistan. Earth System Dynamics, 6(1), 225243.https://doi.org/10.5194/esd-6-225-2015.

Ahmed, M., and Suphachalasai, S. (2014). Assessing the costs of climate change and adaptation in South Asia. Asian Development Bank. http://hdl.handle.net/11540/46.

Aiello, L., Esposito, G., and Ferri, M. A. (2012). Strategic Management and'Complex Products': Some Notes about an Interpretative Model for Business Policies. Business Systems Review, 1(1), 178-201. https://ssrn.com/abstract=2173004.

Akhtar, K., Wang, W., Ren, G., Khan, A., Feng, Y., Yang, G., and Wang, H. (2019). Integrated use of straw mulch with nitrogen fertilizer improves soil functionality and soybean production. Environment international, 132, 105092.https://doi.org/10.1016/i.envint.2019.10 5092.

Akter, S., and Basher, S. A. (2014). The impacts of food price and income shocks on household food security and economic well-being: Evidence from rural Bangladesh. Global Environmental Change, 25, 150162.https://doi.org/10.1016/i.gloenvcha.2014.02. $\underline{003}$.

Ali, E. (2021). Farm Households' Adoption of Climatesmart Practices in Subsistence Agriculture: Evidence from Northern Togo. Environmental Management, 67(5), 949-962. https://doi.org/10.1007/s00267-021-01436-3.

Ali, M., Ahmed, F., Channa, H., and Davies, S. (2015). The role of regulations in the fertilizer sector of Pakistan (No. 1008-2016-79970). 10.22004/ag.econ.211559.

Amrouk, E. M., Grosche, S. C., and Heckelei, T. (2020). Interdependence between cash crop and staple food international prices across periods of varying financial market stress. Applied Economics, 52(4), 345-360.

https://doi.org/10.1080/00036846.2019.164528 $\underline{1 .}$
Cornwall, M., O'Gara, K., Schaap, B., Vayo II, L., and Azeez, K. (2014). The Spatial Distribution of Benefits Resulting from REDD+ and FSC Implementation in Southeastern

Tanzania. https://doi.org/10.1016/i.gloenvcha.2011.03.004. Bosancianu, C. M., Dionne, K. Y., Hilbig, H., Humphreys, M., Sampada, K. C., Lieber, N., and Scacco, A. (2020). Political and social correlates of covid-19 mortality. DOI: $10.31235 /$ osf.io/ub3zd.

Boyce, J. K., Klemer, A. R., Templet, P. H., and Willis, C. E. (1999). Power distribution, the environment, and public health: A state-level analysis. Ecological Economics, 29(1), 127-140. https://doi.org/10.1016/S0921-8009(98)000561

Bryan, E., Ringler, C., Okoba, B., Roncoli, C., Silvestri, S., and Herrero, M. (2013). Adapting agriculture to climate change in Kenya: Household strategies and determinants. Journal of environmental management, 114, 26-35. https://doi.org/10.1016/i.jenvman.2012.10.036.

Butsic, V. A. N., Radeloff, V. C., Kuemmerle, T., and Pidgeon, A. M. (2012). Analytical solutions to trade-offs between size of protected areas and land-use intensity. Conservation Biology, 26(5), 883-893. $\quad$ https://doi.org/10.1111/i.15231739.2012.01887.x.

Carter, M. A., Dubois, L., and Tremblay, M. S. (2014). Place and food insecurity: a critical review and synthesis of the literature. Public health nutrition, 17(1),

94-112. https://doi.org/10.1017/S1368980013000633.

Ceddia, M. G. (2019). The impact of income, land, and wealth inequality on agricultural expansion in Latin America.Proceedings of the National Academy of Sciences, 116(7), 2527-2532. https://doi.org/10.1073/pnas.1814894116.

Ceddia, M. G. (2020). The super-rich and cropland expansion via direct investments in agriculture. Nature sustainability, 3(4), 312-318. https://doi.org/10.1038/s41893-020-0480-2.

Chakraborty, I., and Maity, P. (2020). COVID-19 outbreak: Migration, effects on society, global environment, and prevention. Science of the Total Environment, 728, 138882. https://doi.org/10.1016/j.scitotenv.2020.138882.

Dean, W. R., and Sharkey, J. R. (2011). Food insecurity, social capital, and perceived personal disparity in 
a predominantly rural region of Texas: an individual-level analysis. Social science and medicine, 72(9), 1454-1462. https://doi.org/10.1016/i.socscimed.2011.03.015

Di Falco, S., Veronesi, M., and Yesuf, M. (2011). Does adaptation to climate change provide food security? A micro-perspective from Ethiopia.American Journal of Agricultural Economics, 93(3), 829-846. https://doi.org/10.1093/ajae/aar006.

El-Habil, A. M. (2012). An application on multinomial logistic regression model. Pakistan journal of statistics and operation research, 271-291. https://doi.org/10.18187/pjsor.v8i2.234

Ezeh, A. C., Bongaarts, J., and Mberu, B. (2012). Global population trends and policy options. The Lancet, 380(9837), 142-148. https://doi.org/10.1016/S0140-6736(12)60696$\underline{5}$.

Fanzo, J., Cogill, B., and Mattei, F. (2012). Metrics of sustainable diets and food systems. https://hdl.handle.net/10568/105163.

Fatima, H., and Khan, M. A. (2015). Influence of Wheat Varieties on Technical Efficiency and Production of Wheat Crop in Pakistan (In Selected Area of Punjab). Sarhad Journal of Agriculture, 31(2).http://dx.doi.org/10.17582/jou rnal.sja/2015/31.2.114.122.

Friel, S., Schram, A., and Townsend, B. (2020). The nexus between international trade, food systems, malnutrition, and climate change. Nature Food, 1(1), 51-58. https://doi.org/10.1038/s43016-019-0014-0.

Galbraith, J. K. (2012). Inequality and instability: A study of the world economy just before the great crisis. Oxford University Press. https://doi.org/10.4000/oeconomia.319.

Gitz, V., and Meybeck, A. (2012). Risks, vulnerabilities, and resilience in a context of climate change. Building resilience for adaptation to climate change in the agriculture sector, 23, 19. DOI:10.13140/2.1.4314.8809.

Godfray, H. C. J., and Garnett, T. (2014). Food security and sustainable intensification. Philosophical transactions of the Royal Society B: biological sciences, 369(1639), 20120273. https://doi.org/10.1098/rstb.2012.0273.
Government of Pakistan. Economic Survey. (2019). Finance Division, Economic Advisor's Wing, Islamabad.

https://download1.fbr.gov.pk/Docs/2020612196 4516543PakistanEconomicSurvey2019-20.pdf.

Greene, W. H. (2008). The econometric approach to efficiency analysis. The measurement of productive efficiency and productivity growth, 1(1), 92-250.

Hardaker, J. B., Lien, G., Anderson, J. R., and Huirne, R. B. M. (2015). Integrating beliefs and preferences for decision analysis. Coping with risk in agriculture: applied decision analysis, (Ed. 3), 107-125. DOI:10.1079/9781780645742.0107.

Hussain, A., Aujla, K. M., and Badar, N. (2014). Yield gap determinants for wheat production in major irrigated cropping zones of Punjab, Pakistan. Pakistan Journal of Agricultural Research, 27(3).http://www.pjar.org.pk/Issues/V ol27 2014No_3/p_188.pdf.

Hussain, A., Aujla, K. M., and Badar, N. (2014). Yield gap determinants for wheat production in major irrigated cropping zones of Punjab, Pakistan.Pakistan Journal of Agricultural Research, 27(3).

Hussein, H. (2018). Tomatoes, tribes, bananas, and businessmen: An analysis of the shadow state and of the politics of water in Jordan. Environmental Science and Policy, 84, 170176.https://doi.org/10.1016/i.envsci.2018.03.01 $\underline{8}$.

Ionescu-Ittu, R., Glymour, M. M., and Kaufman, J. S. (2015). A difference-in-differences approach to estimate the effect of income-supplementation on food insecurity. Preventive Medicine, 70, 108-116. https://doi.org/10.1016/i.ypmed.2014.11.017.

Janjua, P. Z., Samad, G., Khan, N. U., and Nasir, M. (2010). Impact of climate change on wheat production: A case study of Pakistan [with comments]. The Pakistan Development Review, 799-822. https://www.jstor.org/stable/41428691.

Jha, P. K. (Ed.). (2015). Proceedings of International Conference on Biodiversity, Livelihood and Climate Change in the Himalayas. Central Department of Botany, Tribhuvan University.

Joshi, N. K., Leslie, T., Rajotte, E. G., Kammerer, M. A., Otieno, M., and Biddinger, D. J. (2015). Comparative trapping efficiency to characterize bee abundance, diversity, and community 
composition in apple orchards. Annals of the Entomological Society of America, 108(5), 785-799. https://doi.org/10.1093/aesa/sav057.

Kabbani, N. (2005). Survey results on hunger and food insecurity in Yemen. Topics in Middle Eastern and North African Economies, 7.https://ecommons.luc.edu/meea.

Kogo, B. K., Kumar, L., and Koech, R. (2020). Climate change and variability in Kenya: a review of impacts on agriculture and food security. Environment, Development and Sustainability, 1-21. https://doi.org/10.1007/s10668-020-00589-1.

Kohansal, M. R., and Firoozzare, A. (2013). Applying multinomial logit model for determining socioeconomic factors affecting major choice of consumers in food purchasing: The case of Mashhad.Journal of Agricultural Science and Technology, 15(7), 1307-1317. http://jast.modares.ac.ir/article-23-5984-en.html.

Kohansal, M. R., and Firoozzare, A. (2013). Applying multinomial logit model for determining socioeconomic factors affecting major choice of consumers in food purchasing: The case of Mashhad.Journal of Agricultural Science and Technology, 15(7), 1307-1317. http://jast.modares.ac.ir/article-23-5984-en.html.

Koleros, A., and Mayne, J. (2019). Using actor-based theories of change to conduct robust contribution analysis in complex settings. Canadian Journal of Program Evaluation, 33(3). https://doi.org/10.3138/cipe.52946.

Kreft, S., Eckstein, D., and Melchior, I. (2013). Global climate risk index 2014. Who suffers most from extreme weather events, 1 ?

Kudaligama, V. P., and Yanagida, J. F. (2000). A comparison of intercountry agricultural production functions: A frontier function approach. Journal of Economic Development, 25(1), 57-74. http://jed.or.kr/full-text/251/kudaligama.PDF.

Laybourn-Langton, L., Rankin, L., and Baxter, D. (2019). This is a crisis: Facing up to the age of environmental breakdown. https://apo.org.au/node/219861.

Lipper, L., Thornton, P., Campbell, B. M., Baedeker, T., Braimoh, A., Bwalya, M. and Torquebiau, E. F. (2014). Climate-smart agriculture for food security. Nature climate change, 4(12), 1068-1072. https://doi.org/10.1038/nclimate2437.

Lobell, D. B., Sibley, A., and Ortiz-Monasterio, J. I. (2012). Extreme heat effects on wheat senescence in India. Nature Climate Change,2(3), 186-189. https://doi.org/10.1038/nclimate1356.

Mahmood, N., Arshad, M., Mehmood, Y., Shahzad, M. F., and Kächele, H. (2021). Farmers' perceptions and role of institutional arrangements in climate change adaptation: Insights from rainfed Pakistan. Climate Risk Management, 32, 100288.https://doi.org/10.1016/i.crm.2021.1002 88.

Mahmood, N., Arshad, M., Mehmood, Y., Shahzad, M. F., and Kächele, H. (2021). Farmers' perceptions and role of institutional arrangements in climate change adaptation: Insights from rainfed Pakistan. Climate Risk Management, 32, 100288.https://doi.org/10.1016/i.crm.2021.1002 88.

Manjunatha, S. B., Biradar, D. P., and Aladakatti, Y. R. (2016). Nanotechnology and its applications in agriculture: A review.J Farm Sci,29(1), 1-13. http://14.139.155.167/test5/index.php/kjas/arti cle/view/7890.

Martin, G. (2015). A conceptual framework to support adaptation of farming systems-development and application with Forage Rummy. Agricultural Systems, 132, 52-61. https://doi.org/10.1016/j.agsy.2014.08.013.

McCordic, C. (2016). Urban infrastructure and household vulnerability to food insecurity in Maputo, Mozambique. http://hdl.handle.net/10012/10191.

Nilsson, M., Griggs, D., and Visbeck, M. (2016). Policy: map the interactions between Sustainable Development Goals. Nature News, 534(7607), 320. doi:10.1038/534320a.

Ogundari, K. (2017). Categorizing households into different food security states in Nigeria: the socioeconomic and demographic determinants. Agricultural and Food Economics, 5(1), 20.https://doi.org/10.1186/s40100-017-0076-y.

Otto, I. M., Kim, K. M., Dubrovsky, N., and Lucht, W. (2019). Shift the focus from the super-poor to the super-rich. Nature Climate Change,9(2), 8284.https://doi.org/10.1038/s41558-019-0402-3. 
Pachauri, R. K., and Reisinger, A. (2008). Climate change 2007. Synthesis report. Contribution of Working Groups I, II and III to the fourth assessment report. $\quad$ http://www.ipcc.ch/ipccreports/ar4syr.htm.

Pinstrup-Andersen, P. (2009). Food security: definition and measurement. Food Security, 1(1), 5-7.

Posner, E. A., and Weisbach, D. 2010. Punishing the Wrongdoers: A Climate Guilt Clause? In Climate Change Justice (pp. 99-118). Princeton University Press. https://doi.org/10.1515/9781400834402$\underline{007 .}$

Pretty, J., Toulmin, C., and Williams, S. (2011). Sustainable intensification in African agriculture. International journal of agricultural sustainability, 9(1), 5-24. https://doi.org/10.3763/ijas.2010.0583.

Rana, M. A. (2018). Commissions and Omissions: Agricultural Produce Markets in Pakistan. Working Paper 01-18-Policy and Institutional Reforms to Improve Horticultural Markets in Pakistan: ACIAR Project 2014/043. Melbourne: Centre for Development Economics and Sustainability, Monash University: https://www. monash. edu/_data/assets/pdf_file/0010/1428769/WP1_ Rana_compl ete. Pdf.

Reader, M. A., Revoredo-Giha, C., Lawrence, R. J., Hodge, I. D., and LANG, B. G. (2018). Farmers' spending on variable inputs tends to maximise crop yields, not profit. International Journal of Agricultural Management, 7(1), 1-11. https://doi.org/10.5836/ijam/2018-07-30.

Reddy, C. S. (Ed.). (2015). Food security and food production: institutional challenges in governance domain. Cambridge Scholars Publishing.

Rehman, Abdul, et al. (2019). Fertilizer consumption, water availability and credit distribution: major factors affecting agricultural productivity in Pakistan.Journal of the Saudi Society of Agricultural $\quad$ Sciences 18.3: 269-274. https://doi.org/10.1016/i.jssas.2017.08.002.

Riddington, G., Sinclair, C., and Milne, N. (2000). Modelling choice and switching behaviour between Scottish ski centres. Applied Economics, 32(8), 10111018.https://doi.org/10.1080/00036840032206 $\underline{6}$.

Ripple, W. J., Wolf, C., Galetti, M., Newsome, T. M., Green,
T. L., Alamgir, M. and Laurance, W. F. (2018). The role of Scientists' Warning in shifting policy from growth to conservation economy. BioScience, 68(4), 239-240. https://doi.org/10.1093/biosci/biy009.

Robert, M., Thomas, A., and Bergez, J. E. (2016). Processes of adaptation in farm decision-making models. A review. Agronomy for sustainable development, 36(4), 1-15. https://doi.org/10.1007/s13593-016-0402-x.

Sani, S., and Kemaw, B. (2019). Analysis of household's food insecurity and its coping mechanisms in Western Ethiopia. Agricultural and food economics, 7(1), 1-20. https://doi.org/10.1186/s40100-019-0124-x.

Sant'Anna, A. A. (2017). Land inequality and deforestation in the Brazilian Amazon. Environment and Development Economics, 22(1), 1-25. https://doi.org/10.1017/S1355770X1600022X.

Sardar Shahraki, A., Ali Ahmadi, N., and Safdari, M. (2019). Economic Analysis of Price Shocks of Production Inputs and Their Impact on Cotton Price in Iran: The Application of Panel Data Vector Auto-Regression (PVAR) Model. Environmental Energy and Economic Research,3(1), 23-36. https://dx.doi.org/10.22097/eeer.2019.159908.1 052.

Siche, R. (2020). What is the impact of COVID-19 disease on agriculture? Scientia Agropecuaria,11(1), 36.http://orcid.org/0000-0003-3500-4928.

Singh, A., and Masuku, M. (2014). Sampling Techniques and Determination of Sample Size in Applied Statistics Research: an Overview. Ijecm. Co. Uk, II (11), 1-22. doi: 10.12691/jpar-3-1-8.

Smith, J., Yeluripati, J., Smith, P., and Nayak, D. R. (2020). Potential yield challenges to scale-up of zero budget natural farming. Nature sustainability, 3(3), 247-252. https://doi.org/10.1038/s41893-0190469-X.

Starkweather, J., and Moske, A. K. (2011). Multinomial logistic regression. file:///C:/Users/taqi/Downloads/MLR JDS Aug2 011\%20(1).pdf.

Taherdoost, H. A. M. E. D., Sahibuddin, S. H. A. M. S. U. L., \& Jalaliyoon, N. E. D. A. (2014). Exploratory factor analysis; concepts and theory.

Tariq, A., Tabasam, N., Bakhsh, K., Ashfaq, M., and 
Hassan, S. (2014). Food security in the context of climate change in Pakistan. Pakistan Journal of Commerce and Social Sciences (PJCSS), 8(2), 540550.http://hdl.handle.net/10419/188154.

Temple, J. B. (2008). Severe and moderate forms of food insecurity in Australia: are they distinguishable? Australian journal of social issues, 43(4), 649668.https://doi.org/10.1002/i.18394655.2008.tb00124.x.

Townsend, B., Schram, A., Baum, F., Labonté, R., and Friel, S. (2020). How does policy framing enable or constrain inclusion of social determinants of health and health equity on trade policy agendas? Critical Public Health, 30(1), 115-126. https://doi.org/10.1080/09581596.2018.150905 9.

Udomkun, P., Ilukor, J., Mockshell, J., Mujawamariya, G., Okafor, C., Bullock, R. and Vanlauwe, B. (2018). What are the key factors influencing consumers' preference and willingness to pay for meat products in Eastern DRC? Food science and nutrition, 6(8), 2321-2336. https://doi.org/10.1002/fsn3.813.

Valters, C. (2014). Theories of change in international development: Communication, learning, or accountability. JSRPaper, 17.https://www.alnap.or $\mathrm{g} /$ system/files/content/resource/files/main/jsrp 17-valters.pdf.

Van Campenhout, B., Pauw, K., and Minot, N. (2018). The impact of food price shocks in Uganda: first-order effects versus general-equilibrium consequences. European Review of Agricultural
Economics, 45(5),

783-807.

https://doi.org/10.1093/erae/jby013.

Vogel, E., and Meyer, R. (2018). Climate change, climate extremes, and global food productionAdaptation in the agricultural sector. Resilience, 31-49. https://doi.org/10.1016/B978-0-12811891-7.00003-7.

Wallimann-Helmer, I., Meyer, L., Mintz-Woo, K., Schinko, T., and Serdeczny, O. (2019). The ethical challenges in the context of climate loss and damage. In Loss and Damage from Climate Change (pp. 39-62). Springer, Cham.https://doi.org/10.1007/978-3-319-7202652 2 .

Wang, Z., Li, J., Lai, C., Wang, R. Y., Chen, X., and Lian, Y. (2018). Drying tendency dominating the global grain production area. Global food security, 16, 138-

149.https://doi.org/10.1016/j.gfs.2018.02.001.

Williams, B., Onsman, A., \& Brown, T. (2010). Exploratory factor analysis: A five-step guide for novices. Australasian Journal

of Paramedicine, 8(3).

Wineman, A. (2016). Multidimensional household food security measurement in rural Zambia. Agrekon, 55(3), 278-301.

Zachary, D. S. (2014). On the sustainability of an activity. Scientific reports 4.1: 1-8. https://doi.org/10.1038/srep05215.

Zeller, R. A. (2005). Measurement error, issues, and solutions: 665-676.

Publisher's note: EScience Press remains neutral with regard to jurisdictional claims in published maps and institutional affiliations. OpY Access This article is licensed under a Creative Commons Attribution 4.0 International License, which permits
use, sharing, adaptation, distribution, and reproduction in any medium or format, as long as you give appropriate credit to the original author(s) and the source, provide a link to the Creative Commons license and indicate if changes were made. The images or other third-party material in this article are included in the article's Creative Commons license, unless indicated otherwise in a credit line to the material. If material is not included in the article's Creative Commons license and your intended use is not permitted by statutory regulation or exceeds the permitted use, you will need to obtain permission directly from the copyright holder. To view a copy of this license, visit http://creativecommons.org/licenses/by/4.0/.

(C) The Author(s) 2021. 
Appendix A. Pprocessing summary of food availability.

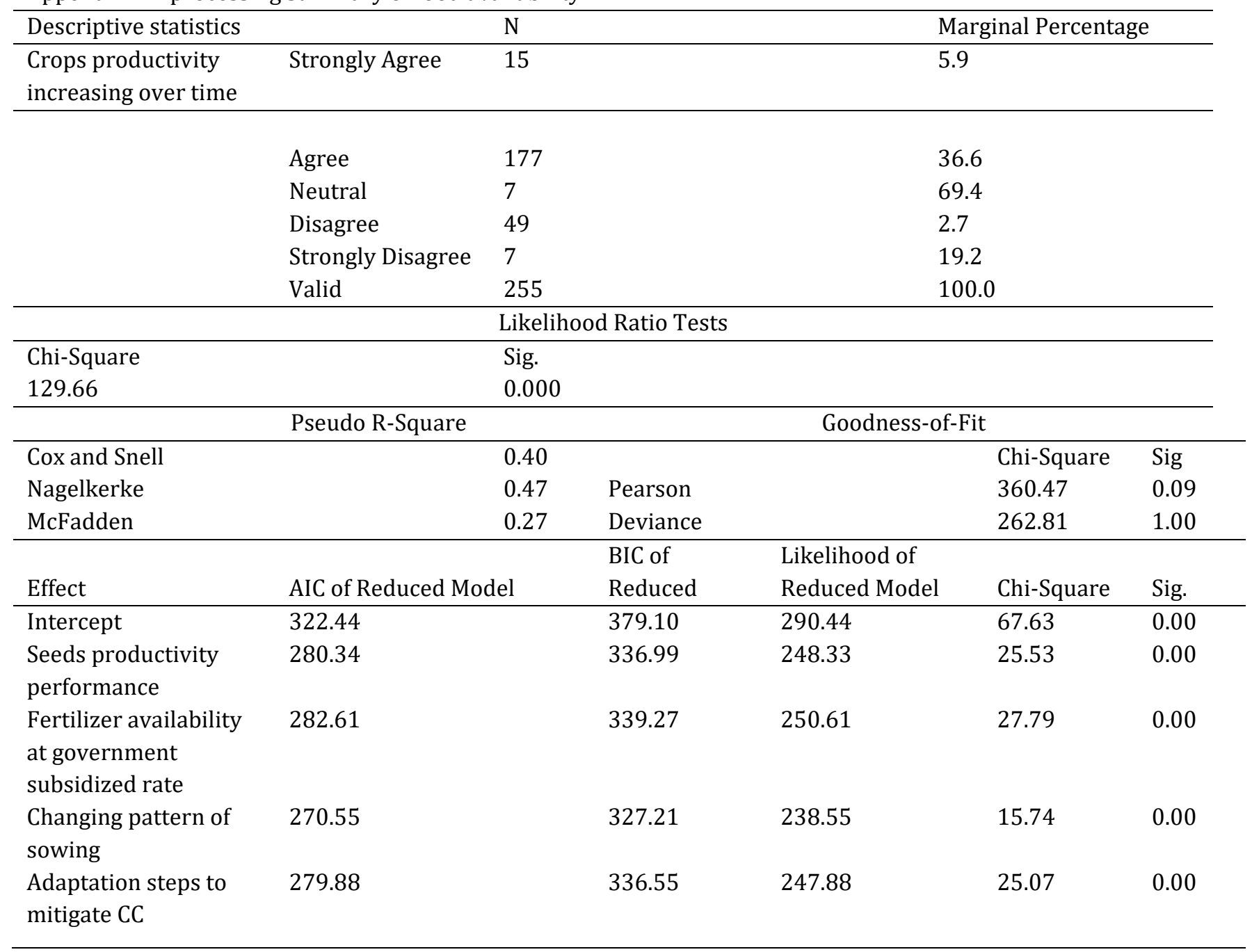


Appendix B. Food sustainability and descriptive statistics.

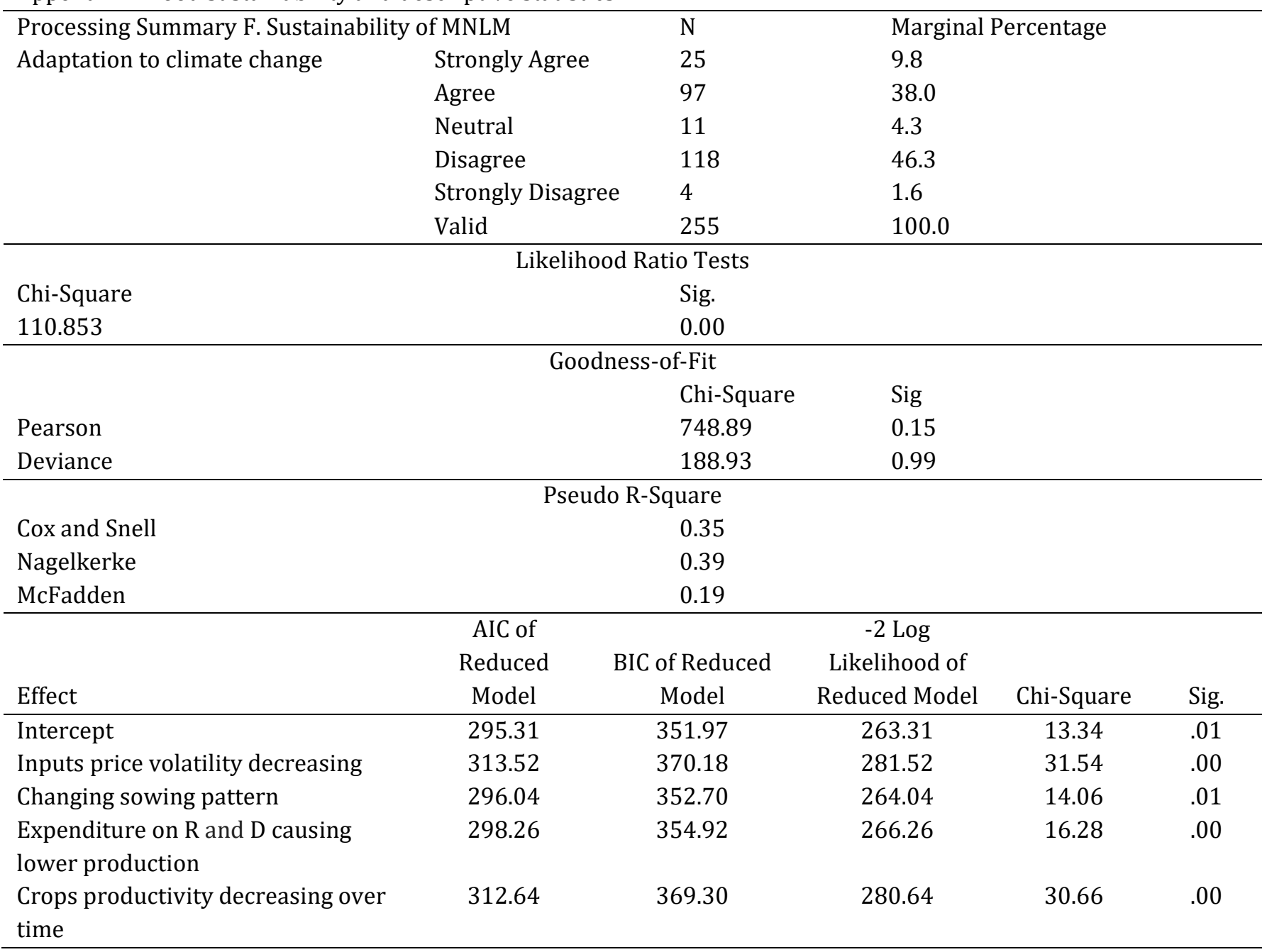

Appendix C. Table Food availability model reliability test

\begin{tabular}{ccc}
\hline & Reliability Statistics & \\
\hline Cronbach's Alpha & $\begin{array}{c}\text { Cronbach's Alpha Based on } \\
\text { Standardized Items }\end{array}$ & N of Items \\
\hline .757 & .723 & 5 \\
\hline
\end{tabular}


Appendix D. Food availability model total statistics.

\begin{tabular}{lccccc}
\hline & \multicolumn{2}{l}{ Item-Total Statistics } \\
& $\begin{array}{l}\text { Scale Mean if } \\
\text { Item Deleted }\end{array}$ & $\begin{array}{l}\text { Scale } \\
\text { Variance if } \\
\text { Item Deleted }\end{array}$ & $\begin{array}{l}\text { Corrected } \\
\text { Item-Total } \\
\text { Correlation }\end{array}$ & $\begin{array}{l}\text { Squared } \\
\text { Multiple } \\
\text { Correlation }\end{array}$ & $\begin{array}{l}\text { Cronbach's } \\
\text { Alpha if Item } \\
\text { Deleted }\end{array}$ \\
\hline $\begin{array}{l}\text { Seed productivity } \\
\text { performance }\end{array}$ & 11.47 & 6.636 & .489 & .276 & .514 \\
\hline $\begin{array}{l}\text { Fertilizer availability at } \\
\text { government subsidized } \\
\text { rate }\end{array}$ & 10.88 & 6.333 & .397 & .284 & .573 \\
\hline $\begin{array}{l}\text { Changing pattern of } \\
\text { sowing }\end{array}$ & 12.46 & 9.950 & .124 & .067 & .659 \\
\hline $\begin{array}{l}\text { Adaptation steps for } \\
\text { climate change }\end{array}$ & 11.42 & 7.795 & .280 & .132 & .623 \\
\hline $\begin{array}{l}\text { Agriculture productivity } \\
\text { is decreasing }\end{array}$ & 11.28 & 6.005 & .620 & .408 & .434 \\
\hline
\end{tabular}

Appendix E. Food sustainability model reliability test

Reliability Statistics

\begin{tabular}{ccc}
\hline Cronbach's Alpha & Cronbach's Alpha Based on Standardized Items & N of Items \\
\hline .798 & .758 & 5 \\
\hline
\end{tabular}

Appendix F. Food sustainability model total items statistics.

\begin{tabular}{lccccc}
\hline & \multicolumn{3}{c}{ Item-Total Statistics } & & \\
\hline & $\begin{array}{c}\text { Scale Mean if } \\
\text { Item Deleted }\end{array}$ & $\begin{array}{c}\text { Scale } \\
\text { Variance if } \\
\text { Item Deleted }\end{array}$ & $\begin{array}{c}\text { Corrected } \\
\text { Item-Total } \\
\text { Correlation }\end{array}$ & $\begin{array}{c}\text { Squared } \\
\text { Multiple } \\
\text { Correlation }\end{array}$ & $\begin{array}{c}\text { Cronbach's } \\
\text { Alpha if Item } \\
\text { Deleted }\end{array}$ \\
\hline $\begin{array}{l}\text { Changing pattern of } \\
\text { sowing }\end{array}$ & 11.23 & 9.903 & .150 & .055 & .644 \\
\hline $\begin{array}{l}\text { Expenditure on R\&D } \\
\text { causing lower } \\
\text { production }\end{array}$ & 10.79 & 7.538 & .210 & .076 & .666 \\
\hline $\begin{array}{l}\text { Agriculture productivity } \\
\text { is decreasing }\end{array}$ & 10.05 & 7.817 & .250 & .107 & .628 \\
\hline $\begin{array}{l}\text { Inputs price volatility } \\
\text { decreasing }\end{array}$ & 10.33 & 5.678 & .644 & .754 & .393 \\
\hline $\begin{array}{l}\text { Adaptation steps for } \\
\text { climate change }\end{array}$ & 10.18 & 5.938 & .692 & .760 & .381 \\
\hline
\end{tabular}

